[Vicino Oriente XVII (2013), pp. 105-114]

\title{
A COPPER JAVELIN HEAD IN THE UCL PALESTINIAN COLLECTION
}

\author{
Daria Montanari - Sapienza University of Rome
}

Il giavellotto di rame presentato in questa sede, conservato nella collezione palestinese dello University College di Londra, è ritenuto proveniente dagli scavi condotti da W.M.F. Petrie nel sito di Tell el-'Ajjul agli inizi del XX secolo. L'arma si presta ad un'analisi tipologica che consente di sostanziare meglio le ipotesi circa il contesto di provenienza e l'attribuzione cronologica.

Keywords: UCL; javelin; Tell el-‘Ajjul; W.M.F. Petrie; Early Bronze IVB

The javelin discussed in this paper is presently preserved in the Palestinian Collection of the Institute of Archaeology of the University College - London, bearing the accession number 2006/19. ${ }^{1}$ As it is stated in the Institute report, it was devoid of marking or labels indicating its provenance. However, according to the Collection Register it probably belonged to the W.M.F. Petrie Palestinian Collection, ${ }^{2}$ most probably from the excavations at Tell el-'Ajjul in the Wadi Gaza, conducted by the British School of Archaeology under William Matthew Flinders Petrie's direction from 1930 to 1934. I was informed about this weapon by Dr. Rachael Sparks, who also allowed me to study it as part of my $\mathrm{PhD}$ research project concerning Early Bronze Age metal weapons in the Southern Levant. ${ }^{3}$ I wish to express to her my sincere gratitude.

\section{UCL COPPER JAVELIN N ${ }^{\circ} 2006 / 19$}

The UCL javelin is made of copper alloy, and it has a massive body, a long leaf-shaped blade, and a coiled and folded tang (fig. 1). The blade has a lozenge-shaped cross-section and a midrib on both faces; the body has a round cross-section; the tang has a squared cross-section due to the hammering and work hardening.

The whole length of the javelin is $29 \mathrm{~cm}$, the blade is $9.8 \mathrm{~cm}$ long, the tang is $7 \mathrm{~cm}$ long; the width of the blade is $1.9 \mathrm{~cm}$; the diameter of the body is $1.1 \mathrm{~cm}$; the thickness of the blade is $0.5 \mathrm{~cm}$; the thickness of the tang is $0.4 \mathrm{~cm}$; the weight is $176 \mathrm{~g}$.

Since no data are available in the UCL Museum Register concerning the provenience of such interesting item, one has, thus, to rely upon a comparative study and on the formation of the UCL collection in order to trace back the origin of the metal weapon.

The leaf-shaped javelin was presumably found during Petrie's archaeological excavations in the cemetery of Tell el-'Ajjul in Southern Palestine. ${ }^{4}$ Two of similar javelins in the UCL Collection were retrieved in Tell el-'Ajjul by W.M.F. Petrie. Even though this find does not appear in Petrie's field reports, there is a certain range of possibility that it was retrieved at Tell el-'Ajjul, such as it is proposed by the Collection Register and as it

\footnotetext{
Ucko - Sparks - Laidlav 2007, 81, cat. 53.
}

Ucko 1998; Sparks 2005; 2013a; 2013b; Ucko - Sparks - Laidlav 2007. A catalogue of of Petrie Palestinian material is available on-line at http://archcat.museums.ucl.ac.uk/.

3 I would like to express my thankfulness to Prof. Lorenzo Nigro, my tutor and guide over the years, who encouraged this my study trip and motivated my $\mathrm{PhD}$ research.

4 The Cemetery $100-200$ is published in Petrie 1931, 8; the Cemetery 1500 is published in Petrie 1932, 14-16. 
suggested by the comparison with the other coeval specimens. ${ }^{5}$ Specifically, as it will be detailed further ( $\$ 3$. ), the javelin 2006/19 shares some features, such as coiled and folded tang and elongated blade, with two specimens from Tombs 227 and 275 of Tell el-'Ajjul.

\section{SOUTHERN LEVANTINE JAVELINS: AN OVERVIEW}

Javelins are deemed a reference class of metal weapons for Southern Levant during the Early Bronze Age. Especially in the Early Bronze IV, javelins figure out as a meaningful presence, in relationship with warfare and social change in that period.

Javelins are long-distance weapons, suitable to be thrown, ${ }^{6}$ composed of two parts of different material: a perishable wooden handle, and a metal point, the head. This weapon was made by melting bronze in a mould, and by hammering and work hardening the molten product.

EB IV Southern Levantine javelin heads usually have a coiled and folded tang to be inserted into the wooden handle; sometimes this part of the haft could be outer reinforced by metallic bends, like as in the case of a specimen from 'Ain Samiya, ${ }^{7}$ strings or fibre strips wrapped around the wooden pole. The tang inserted in the handle corresponds roughly to a third of the whole length of the weapon.

Javelins can be basically subdivided in two main types: the simple one and the leafshaped one. The former type ${ }^{8}$ is represented by a bipartite weapon, with folded, coiled tang, ${ }^{9}$ plain body, squared cross-section, that is the classic "poker-spear", ${ }^{10}$ or with circular cross-section, and a pointed tip. The latter type ${ }^{11}$ is tripartite: it has a folded, coiled tang, a short central body, with alternatively squared or circular cross-section, and the leaf-shaped blade.

The javelin head preserved in the UCL Palestinian Collection belongs to the leaf-shaped type.

\subsection{Leaf-shaped javelins}

Leaf-shaped javelins were mainly found in funerary contexts of Early Bronze IV Southern Levant. More precisely, they were retrieved in Early Bronze IVB $^{12}$ tombs in the

The report of the UCL Collection indicates that the javelin has not yet been matched to a published source.

Yadin 1963, 10.

Dever 1972a, 103-106, fig. 5:3.

8 The simple type corresponds to De Maigret's types A4ii and A4iii (De Maigret 1976, 70-77, figs. 14, 15), and to Philip's types 5 and 13 (Philip 1989, 75-77, fig. 15). It is sometimes in literature referred as "pike".

9 Only in a few cases a straight tang is attested to, like as it is shown by specimens recovered at Byblos (Dunand 1937-1939, 375, pl. C:5493 ), 'Ain Samiya (Dever 1972a, 103-106, fig. 6:6-7), and at el-Musherifeh (Ibrahim - Qadi 1995, 88, fig. 8:3).

10 Woolley 1934, 303; Kenyon 1965, 49.

11 The leaf-shaped type corresponds to De Maigret's types A3iv (De Maigret 1976, 63-67, fig. 12), and to Philip's types 6 and 13 (Philip 1989, 76-77, figs. 17-18).

12 The attribution to that sub-period of the Early Bronze IV is allowed by some pottery vessels recorded in each tomb, characterized by specific features (Nigro 2003a, 134; D'Andrea 2012, 22-23, fig. 3). They are: jars with wheel-made rim and combed band on shoulder, such as in Tomb G 83 at Tell es-Sultan/Jericho (Kenyon 1965, fig. 80:2), in Tombs 2032 (Tufnell 1958, fig. 13, pl. 67:477), 2100 (Tufnell 1958, fig. 13, pl. 67:471), and 2111 (Tufnell 1958, fig. 13, pl. 67:469) at Tell ed-Duweir/Lachish; jar with incised decoration below the 
sites of: Tell es-Sultan/Jericho, ${ }^{13}$ el-Jib/Gibeon, ${ }^{14}$ Tell ed-Duweir/Lachish,,${ }^{15}$ Tell el-'Ajjul, ${ }^{16}$ and in the necropolis of Tiwal esh-Sharqi ${ }^{17}$ in Transjordan. In four cases, leaf-shaped javelins were associated with another weapon, the dagger, ${ }^{18}$ that is: at Tell esSultan/Jericho, Tombs G 83 and M 13, at Tell ed-Duweir/Lachish, Tomb 2111, and at Tiwal esh-Sharqi, Tomb SE.1. ${ }^{19}$

Moreover, six specimens bought on the market, though belonged to funerary equipment, and were probably plundered at 'Ain Samiya, ${ }^{20}$ Jebel Qa'aqīr, ${ }^{21}$ and Khirbet el-Kirmil. ${ }^{22}$ They too are dated to late Early Bronze IV.23

Leaf-shaped javelins might be subdivided into two groups according to the length of the blade in respect of the whole length of the weapon. They could be short or long; the short type has a blade length between 4 and $6.7 \mathrm{~cm}$, and usually exhibits a blade with rounded

wheel-made rim, such as in Tomb 227 at Tell el-Ajjul/Gaza (Petrie 1931, pl XLIV:33, M10); "teapots" with wheel-made rim and combed band on shoulder, such as in Tomb 2032 at Tell ed-Duweir/Lachish (Tufnell 1958, pl. 67:487), or completely combed, such as in Tomb M 13 at Tell es-Sultan/Jericho (Kenyon 1965, fig. 80:11); beaker with wheel-made rim and incised spiral below the rim, such as in Tomb M 13 at Tell esSultan/Jericho (Kenyon 1965, fig. 80:12).

13 Tombs G 83 and M 13 (Kenyon 1965, respectively 150, fig. 41:11; 153, fig. 41:13; Nigro 2003a, 137).

14 Tomb 13 (Pritchard 1963, 20-21, 98, fig. 18:9). This javelin might be dated to the Early Bronze IVB following the guideline established by the author (Pritchard 1963, 21), who linked the weapon to a combed sherd (Pritchard 1963, fig. 18:8), comparable with Early Bronze IVB wave-combed beaker and jar recovered at Tell ed-Duweir/Lachish (Tufnell 1958, pl. 66:404, 423).

15 Tombs 2032, 2100, 2111 (Tufnell 1958, 75-78, respectively pl. 22:2, 3, 1).

16 Tombs 227, 275 (Petrie 1931, 11-12, respectively pl. XIX:49, 48); there is unfortunately no published record belonging to Tomb 275, but the javelin. The Cemetery 100 - 200 is generally dated to Early Bronze IVB (Kenyon 1956, 47).

17 Tomb SE.1 (Tubb 1990, fig. 40b).

18 Garfinkel - Cohen (eds.) 2007, 63. A ceremonial meaning has been proposed for javelins and spearheads associated to daggers (Lapp 1966, 53) or a status-symbol value (Prag 1974, 102; Greenhut 1995, 31); but it is also possible that these weapons were a hallmark of the military specialization of the owner, after accompanied the deceased most of his life, these go together with him also in the tomb (see below $\S 4$.).

19 The Tomb SE.1 contained two individuals, identified as a male and a female. It seems reasonable to attribute the weapons to the male deposition, though these were recovered in the centre of the chamber away from both skeletons, placed near the northern wall (Tubb 1990, 54-55, fig. 39b).

20 Dever 1972a, 103-106, fig. 5:1-3. These weapons were originated together with some Early Bronze IVB pottery vessels, such as combed jars, jars with incision below the rim, wave-combed and incised "teapot" jars, and incised and combed beakers (Dever 1972a, figs. 2-3) from the cemetery of 'Ain Samiya (Dever 1972a, 97).

21 Dever 1972b, 233; 1997, 210-211. The Jebel Qa'aqīr cemetery is dated to the final part of the Early Bronze IV according to the pottery recorded, like as combed jars, combed and wave-combed beakers (Dever 1970, fig. 34; 1972b, 233). Other two javelins, probably of the leaf-shaped type (Dever 1975, 32), were recovered at Jebel Qa'aqīir (London 1985, 97-98).

22 Dever 1975, 31-32, fig. 6:6-7. The pottery repertoire from the cemetery of Khirbet el-Kirmil can be dated to Early Bronze IVB (Dever 1975, figs. 4, 6), except a few vessels that are slightly recent (Dever 1975, fig. 6:2, 4).

23 Cemeteries of central and south of Palestine are more representative of the later part of the Early Bronze IV (Oren 1973, 56, 59-60), as it is confirmed by pottery vessels previously illustrated (fns. 15-17). Looting activities, however, made this dating limitedly reliable. 
tip, rounded base, and a lozenge-shaped cross-section. ${ }^{24}$ The long type, that has a blade length between 7 and $7.5 \mathrm{~cm}$, could have a triangular shaped blade, sometimes with base corners, a marked midrib, and a lozenge-shaped cross-section, that sometimes shows concave sides. ${ }^{25}$

Leaf-shaped javelins generally do not exceed $33 \mathrm{~cm}$ in length and $200 \mathrm{~g}$ in weight.

\section{COMPARISONS TO THE UCL JAVELIN}

On the ground of typological analysis, the UCL javelin 2006/19 represents a wellknown Southern Palestinian type of Early Bronze IV, sharing distinctive features with some already known leaf-shaped specimens. It has a coiled and folded tang, with squared crosssection, such as the javelins recovered at Tell es-Sultan/Jerico, Tomb M 13, ${ }^{26}$ at elJib/Gibeon, Tomb 13, ${ }^{27}$ Jebel Qa'aqīr, ${ }^{28}$ Tell ed-Duweir/Lachish, Tombs 2032 and 2100, ${ }^{29}$ Tell el-'Ajjul/Gaza, Tomb 227, ${ }^{30}$ and a circular central body, like as the other leaf-shaped javelins, (with the exception of two specimens from "Ain Samiya ${ }^{31}$ and Tell esSultan/Jericho, Tomb G $83^{32}$ ). The blade is elongated, as like as of the javelin from Tomb 275 of Tell el-'Ajjul, which shows a dorsal ridge and concave sides, quite similar to another specimen from 'Ain Samiya. ${ }^{33}$

It may be observed that EB IVB cemeteries and tombs where leaf-shaped javelins were retrieved are concentrated in the central and southern region of Palestine, even though a javelin of this type was collected also at Tiwal esh-Sharqi, in Jordan. ${ }^{34}$

\section{Conclusions: CHRONOlogicAl, ARChaEOlogicAl AND SOCIAL CONTEXT OF UCL} COPPER JAVELIN N ${ }^{\circ} 2006 / 19$

If the UCL javelin was part of the conspicuous heritage of antiquity brought to London by Petrie from the Palestinian site of Tell el-'Ajjul, it seems highly probable that it belonged to a funerary context, as it was the case of the other known specimens mentioned above $(\S 2.1 ., 3$.). It might be attribute to a tomb of a grave of the Cemetery $100-200$, where other two leaf-shaped javelins of the same type were recovered, in Tombs 227 and

24 These features are shown by specimens from el-Jib/Gibeon (Pritchard 1963, fig. 18:9), Tell edDuweir/Lachish (Tufnell 1958, pl. 22:1, 3), and Tell el-'Ajjul (Petrie 1931, pl. XIX:49).

25 Concave sides are shown by specimens from Khirbet el-Kirmil (Dever 1975, fig. 6:6-7), and Jebel Qa'aqīr (Dever 1972b, 233). Two specimens exceed the maximum blade length of $7.5 \mathrm{~cm}$, they are one from Khirbet el-Kirmil (Dever 1975, 31-32, fig. 6:6), with a $10 \mathrm{~cm}$ blade, and one from Jebel Qa'aqīr (Dever 1972b, 233), with a $14 \mathrm{~cm}$ blade. The UCL javelin head has overall dimensions and tripartite measures almost equal to that of Khirbet el-Kirmil.

26 Kenyon 1965, fig. 41:13; this item seems to have a squared cross-section only at the tip of the tang.

27 Pritchard 1963, fig. 18:9.

28 Dever 1972b, 233.

29 Tufnell 1958, respectively pl. 22:2, 3.

30 Petrie 1931, pl. XIX:49.

31 Dever 1972a, fig. 5:1.

32 Kenyon 1965, fig. 41:11.

33 Dever 1972a, fig. 5:3.

34 Tubb 1990, 96. 
$275,{ }^{35}$ while no javelins at all were retrieved in the Cemetery $1500,{ }^{36}$ the other necropolis of Tell el-'Ajjul.

On the basis of the considerations illustrated above, UCL javelin head 2006/19, sharing common features with a series of leaf-shaped specimens ( $§ 3$.), may be convincingly attributed to a distinguished type attested in Southern Levant during Early Bronze IVB. It seems strongly distinctive of a group of funerary equipment, which may be attributed to EB IV warriors, ${ }^{37}$ also because javelins are usually associated with other weapons, namely daggers. ${ }^{38}$

Moreover, the appearance of javelins, and especially of the leaf-shaped type during the Early Bronze IVB should be reconsidered in regard to the introduction of new technologically advanced skills and to the spreading of new weapon types. Throughout the Early Bronze IV in addition to javelins some new weapons make their appearance in funerary contexts, such as fenestrated axes of the broad earlier type ${ }^{39}$ hooked and socketed spearheads, ${ }^{40}$ all of them possibly characteristic of warrior burials too. ${ }^{41}$

35 Petrie 1931, 11-12, respectively pl. XIX:49, 48.

36 Petrie 1932, 14-16.

37 Palumbo 1990, 109; Philip 1995, 140, 151; Nigro 1999, 16. Despite the fact that bronze objects in general and weapons in particular were precious items, they were nevertheless buried with their owners. This suggests that during this period weapons were the personal possessions of a warrior and were not controlled by a central authority or stored together in a community arsenal. Weapons were considered personal belonging; at the warrior's death, they were buried with him, letting go out of circulation costly weapons (Garfinkel 2001, 156157).

38 Simple javelins, as it is shown by Tomb A41 at Dhahr Mirzbaneh (Lapp 1966, fig. 24:12-13), Tomb 50 and 52 at el-Jib/Gibeon (Pritchard 1963, 54-56, figs. 56:8-9, 58:6-7), Tomb A1 at el-Musheirfeh (Ibrahim - Qadi 1995, 88, fig. 8:1-3), Tomb M16 at Tell es-Sultan/Jericho (Kenyon 1965, 153-155, fig. 41:14-15), and Tomb 1 at Amman (Zayadine 1978, 66, fig. 4:6-7), and leaf-shaped javelins, such as in the case of Tomb 2111 at Tell ed-Duweir/Lachish (Tufnell 1958, 75-78, pl. 22:1, 4), Tombs G 83 and M13 at Tell es-Sultan/Jericho (Kenyon 1965, 150, 153, figs. 41:10-11, 41:12-13), and Tomb SE1 at Tiwal esh-Sharqi (Tubb 1990, 53-58, fig. 40b) can be associated to daggers in funerary equipments.

39 Fenestrated axes recovered in tombs are those from Tell el-Mutesellim/Megiddo (Guy 1938, 115, pl. 163:8), Ma'abarot (Gophna 1969, 174-177, fig. 2), 'Enot Shuni (Caspia et al. 2008, fig. 1:a-b), and Tell Mastaba (Beth Shan; Tzori 1962, 153). To these already mentioned as belonging a new type the anchor axes from Beit Ulla and Kfar Malek should be added (Nigro 2003b, 15, fig. 8; www.antiques.com/classified/1040823/Antique-Bronze-Fenestrated-Axe-Head---FZ-075; www.antiques.com/classified/1040829/Antique-Bronze-Fenestrated-Axe-Head---FZ-079).

40 Hooked spearheads were recovered in tombs at Tell el-Hosn/Beth Shan (Oren 1973, X, 77, figs. 20:3; 21:14, 20), Tiberias (Tzaferis 1968, 19, pl. 1A); Geva-Carmel (Amiran 1974, fig. 1:5), Kinnutz Hazorea (Meyerhof 1989, 128, pl. 35:3:103), Fureidis (Hess 1980, fig. 1:7), Ma'abarot (Dar 1977, 62:7, 13, 14, 16), Ginosar (Epstein 1974, 3*, fig. 4:11), Khirbet Beth Mizza/Motza (Bahat 1975, fig. 5:1), Horbat Gilan South (Mahajna 2006, fig. 3), and in the Wadi Hamra (Stepansky 2005, fig. 1). Socketed spearheads were registered in tombs at Tell el-Mutesellim/Megiddo, in Tombs 1101B Lower and 84C (Guy 1938, 26-27, 115, 163, fig. 174:1, pls. 86:3; 163:9), el-Jib/Gibeon (Pritchard 1963, 61, fig. 64:12-13), and in two dolmen in the Golan (Epstein 1985, 43, figs. $2: 9 ; 3: 18)$.

41 Usually spearheads are not associated to javelins in burials, but sometimes spearheads are in the same funerary equipment together with fenestrated axes, as it is in the case of Tombs 1101B Lower and 84C (Guy 1938, 26-27, 115, 163, fig. 174:1, pls. 86:3; 163:9). 
The occurrence and association of different weapons within funerary equipment ${ }^{42}$ (javelin + dagger or dagger + spearhead) first of all show that only a single ranged weapon was usually added to warrior burial. Secondly, it suggests that warriors existed with a specific weaponry, possibly depending on their specialization. ${ }^{43}$

Warriors burials are a distinguishing feature of the final phase of the Early Bronze IV in the Southern Levant, which is indeed the Early Bronze Age sub-period with the highest attestation of weapons. Warriors burials have be seen as strongly connected with similar tombs of following Middle Bronze Age period, thus pointing to the emerging of a warriors class in Southern Levant in this period. ${ }^{4}$

New types of weapons, as the UCL leaf-shaped javelin, and new burial patterns, as the warrior tombs, reflect social changes and the formation of new social balances during the non-urban interval at the turn of the $3^{\text {rd }}$ millennium $\mathrm{BC} .{ }^{45}$

\section{REFERENCES}

\section{AMIRAN, R.}

1974 A Tomb-Group from Geva'-Carmel: 'Atiqot Hebrew Series 7 (1974), pp. 1*-12*.

BAHAT, D.

1975 A Middle Bronze I Tombe Cave at Motza: Eretz Israel 12 (1975), pp. 18*-23*.

Caspia, E.N. - Rivin, O. - Ettedgui, H. - Peilstöcker, M. - Shilstein, S. - Shalev, S.

2008 Non-destructive Neutron Diffraction Study of Internal Structure of Archaeological Metal Artifacts from Israel: 9th International Conference on NDT of Art, Jerusalem Israel, 2530 May 2008, www.sciencedirect.com/science.

COHEN, S.L.

2012 Weaponry and Warrior Burials: patterns of disposal and social change in the southern Levant: R. MATTHEWS - J. CURTIS (eds.), Proceedings of the 7th International Congress on the Archaeology of the Ancient Near East 12 April - 16 April 2010, the British Museum and UCL, London, Wiesbaden 2012, pp. 307-319.

D'ANDREA, $\mathrm{M}$.

2012 The Early Bronze IV Period in South-Central Transjordan: Reconsidering Chronology through Ceramic Technology: Levant 44 (2012), pp. 17-50.

DAR, S.

1977 Ancient Settlement of 'Emeq Hefer. The Sites of Tell Nurit, Nahal Alexander and the De Maigret, A Rockcut Tombs of Ma'abarot, Kibbutz Ma'abarot 1977.

1976 Le lance nell'Asia Anteriore nell'Età del Bronzo (Studi Semitici 47), Roma 1976.

Doumet-Serhal - Griffiths 2007-2008, 202.

Palumbo 1990, 131.

44 Oren 1971, 109; Philip 1995, 145, 153; Thalmann 2000, 50-53; Doumet-Serhal 2004, 175; Doumet-Serhal Kopetzky 2011-2012, 9-10; Cohen 2012, 309.

45 Nigro 2003a, 121. 
DEVER, W.G.

1970 The "Middle Bronze I" Period in Syria and Palestine: J.A. SANDERs (ed.), Essays in Honor of Nelson Glueck. Near Eastern Archaeology in the Twentieth Century, New York 1970, pp. 132-163.

1972a Middle Bronze Age I Cemetery at Mirzbaneh and 'Ain Samiya: Israel Exploration Journal 22 (1972), pp. 95-112.

1972b A Middle Bronze I Site on the West Bank of the Jordan: Archaeology XXV (1972), pp. 231-233.

1975 A Middle Bronze I Cemetery at Khirbet el-Kirmil: Eretz Israel 12 (1975), pp. 18-33.

1997 Jebel Qa'aqiir: E.M. MEYERS (ed.), The Oxford Encyclopedia of Archaeology in Near East, vol. 3, Oxford 1997, pp. 201-211.

DOUMET-SERHAL, C.

2004 Weapons from the Middle Bronze Age Burials in Sidon: C. Doumet-Serhal (ed.), Decade. A Decade of Archaeology and History in the Lebanon (Archaeology and History in the Lebanon Special Edition), Beirut 2004, pp. 154-177.

DOUMET-SERHAL, C. - GRIFFITHS, D.

2007-2008 Bronze Artifacts from Burial 42 at Sidon: H. ChARAF (ed.), Inside the Levantine Maze. Archaeological and Historical Studies Presented to Jean-Paul Thalmann on the Occasion of his Sixtieth Birthday (Archaeology and History in the Lebanon 26-27), Beirut 20072008, pp. 194-203.

DOUMET-SERHAL, C. - KOPETZKY, K.

2011-2012 Sidon and Tell el-Dab'a: Two Cities - One Story. A Highlight on Metal Artefacts from the Middle Bronze Age Graves: C. Doumet-Serhal - A. RABAte - A. Resek (eds.), And Canaan Begat Sidon his Firstborn. A tribut to Dr. John Curtis on his $65^{\text {th }}$ birthday DUNAND, M. (Archaeology \& History in the Lebanon 34-35), Beirut 2011-2012, pp. 9-52.

1937-1939 Fouilles de Byblos, 1926-1932, Paris 1937-1939.

EPSTEIN, C.

1974 Middle Bronze Age Tombs at Kefar Solzd and Ginosar: 'Atiqot Hebrew Series 7 (1974), pp. $13 *-39 *$.

1985 Dolmens Excavated in Golan: 'Atiqot 17 (1985), pp. 20-58.

GARFINKEL, Y.

2001 Warrior Burial Customs in the Levant in the Early Second Millennium B.C.: S. WoLfF (ed.), Studies in the Archaeology of Israel and Neighboring Lands in Memory of Douglas L. Esse (Studies in Ancient Oriental Civilization 59), Chicago 2001, pp. 143-161.

GARFINKEL, Y. - COHEN, S. (eds.)

2007 The Middle Bronze Age IIA Cemetery at Gesher. Final Report (The Annual of the GOPHNA, R American Schools of Oriental Research 62), Boston 2007.

1969 A Middle Bronze Age I Tomb with Fenestrated Axe at Ma'abarot: Israel Exploration Journal 19 (1969), pp. 174-177.

GREENHUT, Z

1995 EB IV Tombs and Burials in Palestine: Tel Aviv 22 (1995), pp. 3-46. GUY, P.L.O.

1938 Megiddo Tombs (Oriental Institute Publications 33), Chicago 1938.

HESS, O.

1980 A Middle Bronze age I Burial Cave at Fureidis: 'Atiqot 14 (1980), pp. 34-36. 


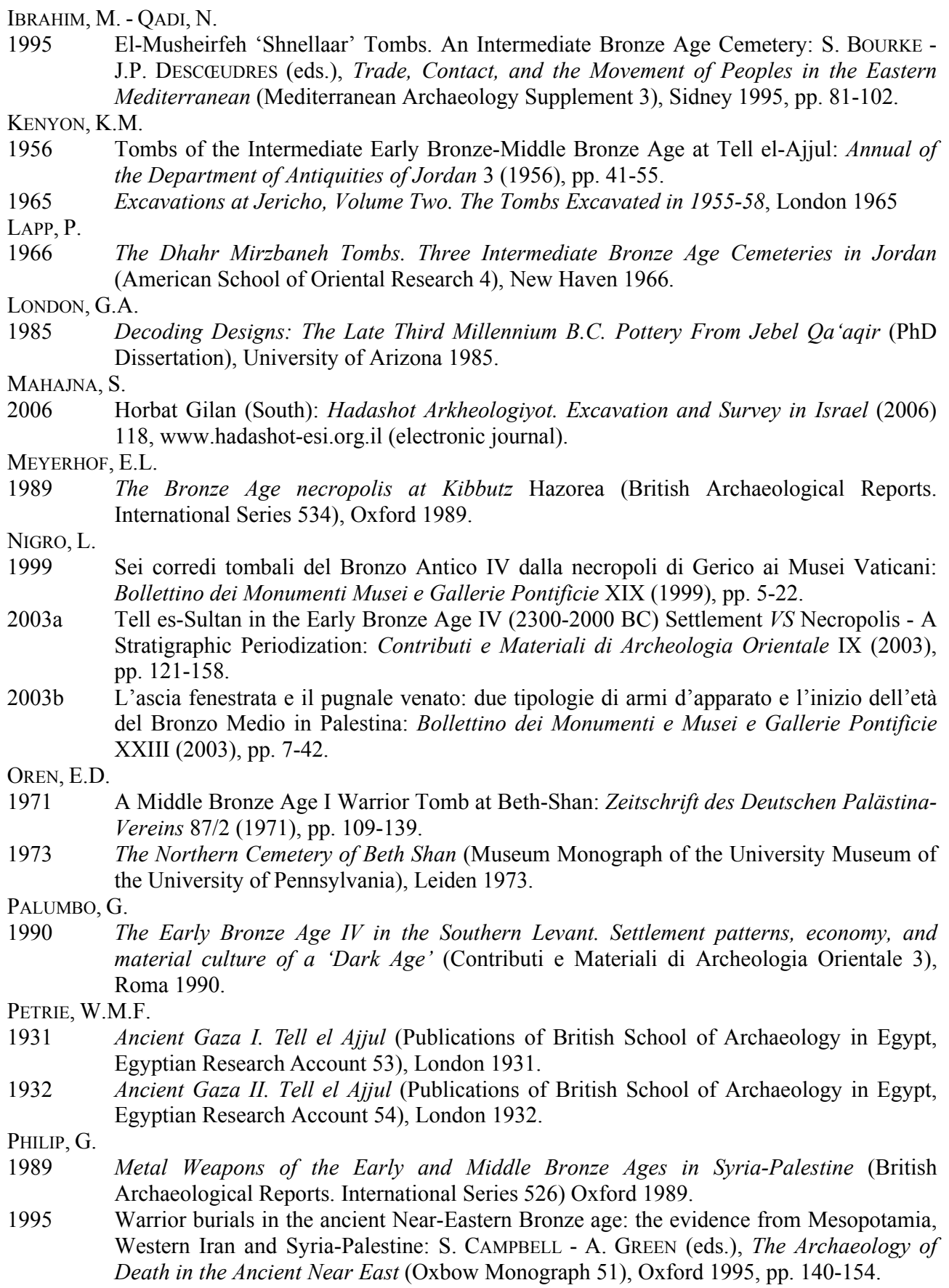

2003a Tell es-Sultan in the Early Bronze Age IV (2300-2000 BC) Settlement VS Necropolis - A Stratigraphic Periodization: Contributi e Materiali di Archeologia Orientale IX (2003), pp. 121-158.

2003b L'ascia fenestrata e il pugnale venato: due tipologie di armi d'apparato e l'inizio dell'età del Bronzo Medio in Palestina: Bollettino dei Monumenti e Musei e Gallerie Pontificie XXIII (2003), pp. 7-42.

OREN, E.D.

1971 A Middle Bronze Age I Warrior Tomb at Beth-Shan: Zeitschrift des Deutschen PalästinaVereins 87/2 (1971), pp. 109-139.

1973 The Northern Cemetery of Beth Shan (Museum Monograph of the University Museum of the University of Pennsylvania), Leiden 1973.

Palumbo, G.

1990 The Early Bronze Age IV in the Southern Levant. Settlement patterns, economy, and material culture of a 'Dark Age' (Contributi e Materiali di Archeologia Orientale 3), PETRIE, W.M.F Roma 1990.

1931 Ancient Gaza I. Tell el Ajjul (Publications of British School of Archaeology in Egypt, Egyptian Research Account 53), London 1931.

1932 Ancient Gaza II. Tell el Ajjul (Publications of British School of Archaeology in Egypt, PHILIP, G.

1989 Metal Weapons of the Early and Middle Bronze Ages in Syria-Palestine (British Archaeological Reports. International Series 526) Oxford 1989.

1995 Warrior burials in the ancient Near-Eastern Bronze age: the evidence from Mesopotamia, Western Iran and Syria-Palestine: S. CAMPBELl - A. GREEN (eds.), The Archaeology of Death in the Ancient Near East (Oxbow Monograph 51), Oxford 1995, pp. 140-154. 
PRAG, K.

1974 The Intermediate Early Bronze-Middle Bronze Age: an Interpretation of the Evidence from Transjordan, Syria and Lebanon: Levant 6 (1974), pp. 69-116.

PRITCHARD, J. B.

1963 The Bronze Age Cemetery at Gibeon, Philadelphia 1963.

SPARKS, R.T.

2005 The Lost Loci of Tell el-‘Ajjul: Petrie's Area C: Palestine Exploration Quarterly 137 (2005), pp. 23-29.

2013a Publicising Petrie: Financing Fieldwork in British Mandate Palestine (1926-1938): Present Past 5/1 (2013), pp. 1-15.

2013b Flinders Petrie Through Word and Deed: Re-evaluating Petrie's Field Techniques and their Impact on Object Recovery in British Mandate Palestine: Palestine Exploration Quarterly 145 (2013), pp. 143-159.

STEPANSKY, Y.

2005 Zefat: Hadashot Arkheologiyot. Excavation and Survey in Israel 117 (2005), www.hadashot-esi.org.il (electronic journal).

THALMANN, J.P.

2000 Tell Arqa: Bulletin d'Archéologie et d'Architecture Libanaises 4 (2000), pp. 5-74.

TUBB, J.N.

1990 Excavations at the Early Bronze Age Cemetery of Tiwal esh-Sharqi, London 1990.

TUFNELL, O.

$1958 \quad$ Lachish IV (Tell ed-Duweir) The Bronze Age, Oxford 1958.

TZAFERIS, $\mathrm{V}$.

1968 A Middle Bronze Age I Cemetery in Tiberias: Israel Exploration Journal 18 (1968), pp. $15-19$.

TZORI, N.

1962 Survey of the Beth Shan Valley: The Beth Shan Valley. 17th Archaeological Convention, Jerusalem 1962, pp. 135*-198*.

UCKO, P.J.

1998 The biography of a collection: The Sir Flinders Petrie Palestinian Collection and the role of University Museums: Museum Management and Curatorship 17 (1998), pp. 351-399.

UCKO, P.J. - SPARKS, R.T. - LAIDLAW, S.

2007 A Future for the Past: Petrie's Palestinian Collection. An Exhibition Held in the Brunei Gallery, London 2007.

WOOLLEy, C.L.

1934 Ur Excavations II. The Royal Cemetery. A Report on the Predynastic and Sargonic Graves Excavated between 1926 and 1931, London 1934.

YADIN, Y.

1963 The Art of Warfare in Biblical Lands: In the Light of Archaeological Study, Jerusalem 1963.

ZAYADINE, F.

1978 An EB-MB Bilobate Tomb at Amman: P.R.S. MOOREY - P.J. PARR (eds.), Archaeology in the Levant: Essays in Honor of Kathleen M. Kenyon, Warminster 1978, pp. 59-66. 

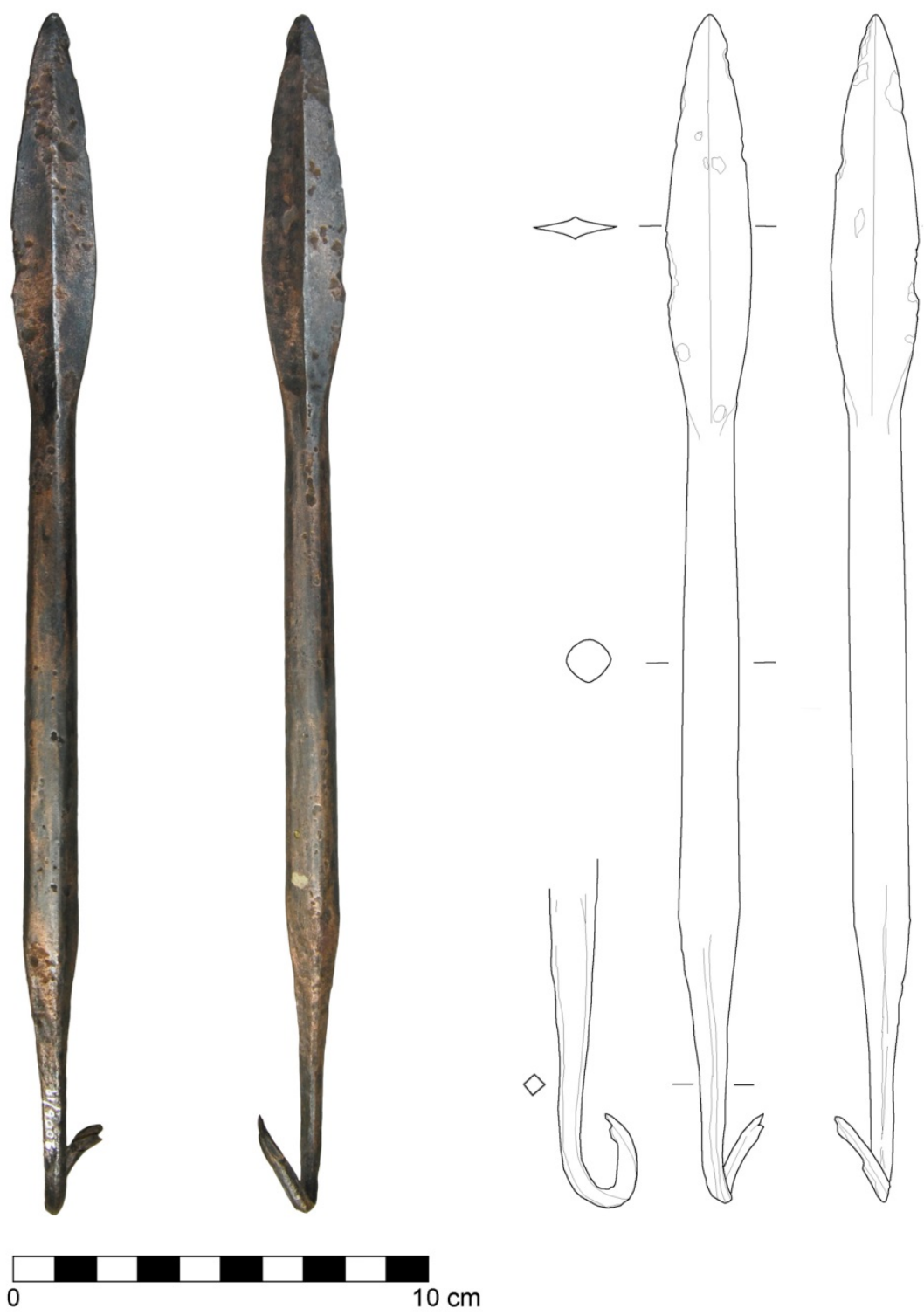

Fig. 1 - Photo and drawing of Early Bronze IVB UCL javelin 2006/19, courtesy of Institute of Archaeology of University College London (photo and drawing by the author). 